\title{
Islam and the Rearrangement of Society-State Relation in the Reformation Era of Indonesia
}

\author{
YUSDANI $^{1}$
}

\begin{abstract}
This article discusses the thoughts of Nurcholish Madjid and Abdurrahman Wahid regarding democratization in the reform era of Indonesia. It focuses on how Islam is articulated and implemented according to these two thinkers in the context of the changing of society-state relation in the reform era of Indonesia. To analyse and elaborate on their thoughts, the sociological and historical approaches as well as the prophetic sociology of knowledge are utilised or applied. It is argued here that the religio-political thoughts of the two thinkers go beyond a procedural democracy, arguing for a kind of democracy that is based on ethics and rationality where the relationship between strong society and the effective state in Indonesia is solidified and dignified.
\end{abstract}

Keywords: Abdurrahman Wahid, Islam in Indonesia, Nurcholish Madjid, postSuharto, society-state relation

After the collapse of the New Order in Indonesia, there is the growing pressure to reformulate the tasks and roles of the Indonesian state and government. The state, in this context, is no longer imagined as the single force given the full mandate to carry out the activities needed to protect the citizens of the state and the nation; the state plays its roles or functions only as the guardian of the rules of the games by facilitating the interaction of fellow citizens and the state precisely is in position to always be controlled (Haryatmoko 2003: 212). The discourse of good governance, which has been rampant lately, marks the strong idea that the state must be reduced in its roles in managing public spheres (Sedarmayanti 2003: 4).

The New Order or Orde Baru or Orba in Indonesian language was the term coined by the second Indonesian President Suharto to characterize his regime as he came to power in 1966 as well as to differentiate his regime from his predecessor the first Indonesian President Sukarno. However, Suharto could not sustain his New Oder after his three-decade-long presidency because the Indonesians demonstrated against him and demanded him to step down. Finally, Suharto stepped down in May 1998 and his New Order collapsed.

The study of Islamic thought that has developed so far shows how strong the desire among Indonesian Muslims to respond to the challenges and influences of the global market. In this connection, Islamic thinkers aware that whatever the pattern of society-state relation is to be applied in Indonesia, the most affected citizens are the Muslims who are the largest number among Indonesian citizens. Therefore, the Muslims in Indonesia need to ensure that the roles of the state remain within the corridors of their Islamic religious teachings. Against this background, this article seeks to examine the responses of Islamic thoughts to the changes in society-state relation in Indonesia in the reformation era focusing on the religio-political thoughts of two

\footnotetext{
1 Yusdani, Ph.D., professor at Doctoral Program of Islamic Law, the Faculty of Islamic Studies, Islamic University of Indonesia, YOGYAKARTA 55584, Indonesia, email: yusdani@uii.ac.id.
} 
leading Indonesian Muslim intellectuals namely Nurcholish Madjid (Cak Nur) and Abdurrahman Wahid (Gus Dur).

\section{The Theoretical Framework}

Islamic studies in Indonesia are studied based on certain typologies and models such as Islamic theology, Islamic law, Islamic ethics, Islamic jurisprudence, Islamic politics, Islamic finance, Islamic rituals and Islamic history These typologies and models of Islamic studies in Indonesia have raised several problems. In addition to some overlapping typologies, they also have limitations in depicting and photographing the dynamics of Islamic thought in the religious level and in the responses to the dynamics of the politico-religious and state-government dynamic trends. Other typologies and models in Islamic studies in Indonesia use the cultural approach and security approach. The framework of the cultural approach places more emphasis on how Muslim individuals or Islamic organizations interpret the Islamic religious scriptures and their impacts on the political ideas, decisions and actions or behaviours. This cultural framework is dominantly used in studying Islam in Indonesia (Hadiz 2011) while the security framework is widely used by some researchers who do not understand the teachings of Islam (Voll 1982: 2-4). The impact of these two frameworks has led to the emergence of some vague indicators in Islamic thought. In fact, it gave birth to the categorization of the good and the bad Muslims, the moderate Islam and the radical Islam (Hadiz 2011). In addition, there have been the simplification and reduction of the Muslim problems and Islamic teachings instead of the dynamics and complexity of Islamic teachings and Islamic thought (Bayyah 2007).

The present study of Islamic thought in the context of changing society-state relations in Indonesia in the reform era uses the political economy approach (Hadiz 2016). Consequently, the study is linked to the complexity of the problems in the social and internal environment faced by Islamic leaders and the liberalization of the global economy as a context. Therefore, to track and analyse the mind-sets of Nurcholish and Abdurrahman, the three-dimensional analysis is used in understanding the reality of Islamic thought which always involves internalization, objectification, and externalization (Kuntowijoyo 2001). Consequently, the responses of Islamic thought to the changes in society-state relations in Indonesia as articulated and expressed by Nurcholish Madjid and Abdurrahman Wahid are analysed and presented here by taking into consideration the interaction between the three dimensions of Islamic thought as well as the politico-economic approach.

\section{The Rearrangement of Society-State Relation in the Reformation Era}

Nurcholish Madjid (popularly called Cak Nur) was born in Mojoanyar, Jombang, East Java, on March 17, 1939 and died on August 29, 2005 (Madjid 1995). As a Muslim, Cak Nur sought to interpret Islam in the Indonesian context. The result of his thinking was Indonesian Islam (Nafis 2014: 326). His thought seeks to present a culturally, inclusive and constructive face of Islam that is responsive and adaptive to the challenges of the times (Madjid 1998). Cak Nur developed his thoughts based on the basic framework of Islamic traditions but the externalization (or implementation) of his thoughts was in accordance with the Indonesian context (Madjid 1995: 469).

Likewise, Abdurrahman Wahid (popularly called Gus Dur) is a figure whose ideas are based on Islam and the traditions of the pesantren. Abdurrahman Wahid, the grandson of the two NU founders, Kiai Hasjim Asj'ari and Kiai Bisri Sjansuri, was born in Jombang on August 4, 1940 (Ahmad 2010: 8) and died on December 30, 2009. Among the most important thoughts of Nurcholish Madjid and Abdurrahman Wahid are their defence of the society's interests and their struggles to maintain a plurality of cultures, ethnicities, and religions (Mahfud 2013). 
The NU is the abbreviated noun for Nahdlatul Ulama founded in January1926 in Surabaya, Indonesia as a response to the rise of Wahhabism in Saudi Arabia and Islamic modernism in Indonesia. The NU has been the traditionalist Sunni Muslim movement or organization in Indonesia following Islamic law as advocated by the Shafi'ites. Gus Dur was the leader of the NU for many years before he became the president of Indonesia from 1999 to 2001.

Both thinkers, Nurcholish Madjid and Abdurrahman Wahid, uphold the view that the society needs to be positioned as the real powerful society to build the democracy in the context of society-state relation in the reform era. Their position is different from the position of the kawula or wong cilik. The position of the kawula shows that the society does not have roles and rights in the state. Therefore, the roles and rights of the state are to dominate and control the society. Whereas the position of the wong cilik (a small citizen) explains that the society has the rights and the roles in the state, although their rights and roles are very limited. This reality can be understood from the reality of society-state relation in Indonesia, especially in the New Order era. However, the position of the society as the citizens of the state, has the rights and roles in the modern sense related to the society-state relation (Kuntowijoyo 2001). The position or the status of the state citizens has some implications for the pattern of society-state relation as thought and voiced by both Indonesian Muslim thinkers popularly known as Cak Nur and Gus Dur for all Indonesian citizens in the reform era in Indonesia.

According to both Cak Nur and Gus Dur, there are the conditions required to develop this kind of the society-state relation in the reform era in Indonesia. The first condition is the willingness of the state to position the society as the state full citizens. The second one is the state and ruling elite class must be considered as the servants of the society (Mulkhan 2009: 204). The third condition is the society should be free from any form of state intervention and the hegemony of the ruling elite class. In this way, the ideal society-state relation is a form of social life where the society is the main actors with the state and law, and the ruling elite class does function as the servants of the society. Since the state is the servant of the society, if the state provides the good services to the society, the goals of the state and society namely justice, prosperity and welfare are realized in Indonesia (al-Ghazali n.d).

The various explanations above indicate that the relationship between the society and the state should be in a strong position. The strong (effective) state means that it can carry out its functions of providing security protection, guaranteeing economic welfare, creating social order, maintaining territorial integration, while the strong society can be interpreted as having the ability to control the state if it leads to the authoritarian decisions and practices as well as the power abuses of power and injustices (Manan 2005: 261-262).

The approach used in the above reading of the relationship between the state and society is the historical approach with the challenge and response model (Toynbee 1955). In addition, the sociological approach inspired by humanization, liberation and transcendence, derived from the historical and ethical mission of Islam is also used. This special sociological approach is the objectification (Kuntowijoyo 2001) process which is the transformation of the subjective values of religion into the objective categories that can be understood and accepted by all society without the need to agree on their original values. Thus, the objectification is the method or strategy of these two figures to present Islam more substantively and ethically. In the objectification, the objective values of all religions, ideologies, beliefs or philosophical schools can communicate with each other (Kuntowijoyo 1997; Santoso 2012). The sociological analysis of knowledge in understanding the responses of Islamic thoughts expressed by Cak Nur and Gus Dur can explain the dialectical connection between these two Muslim thinkers and the context and reality of changes in society-state relation in Indonesia in the reform era (Fanani 2010: 54). The dialectical connection takes place in the three-stage-thinking process simultaneously, namely internalization, objectification, and externalization

The Islamic thinking responses of Cak Nur and Gus Dur to the changes in the society-state relation in Indonesia in the reform era indicate the urgency of the functions of the state in the 
lives of Indonesians who are predominantly Muslims. For these two Muslim thinkers, the functions of the state in the lives of Indonesians are not merely the passive nachtwachterstaat (the state of the night guard), that is, the new state is present and acts if the basic rights of the society are violated, the order and security are interrupted and the economic system is the laissez faire. Thus, the state must play an active role in building and maintaining the welfares of the society (al- Mawardi n.d: 139).

The responses of Cak Nur and Gus Dur are in accordance with the state-science approach, Azhari (2013) stating that the status of the Indonesian state is not only an economic instrument but also a legal instrument to realize the social justice for the Indonesian society. Based on their thoughts and responses for the effective state in the reform era, both Cak Nir and Gus Dur affirmatively uphold that the society must also be strong in the sense of sovereignty. The pattern of sovereign society and effective state relation can be illustrated in the following chart.

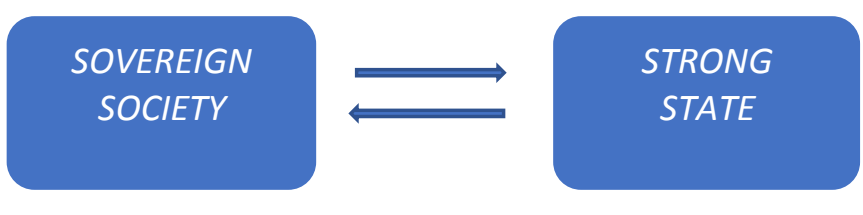

The pattern of relation between sovereign society (Al-Mawardi n.d) and effective state is a pattern of relation that positions the society and state in a check and balance relationship, in the sense that there is no party that is more dominant than the other party. The state is effective because the state has strong constitutional legitimacy and a broad base of support from the society (Hiariej 1998; Manan 2005). The effective state is the state with the power and ability to carry out its functions in providing security and protection, guaranteeing economic welfare, creating and maintaining social order, and safeguarding its territorial integration (Manan 2005). The sovereign society is the society with the increasing political awareness, the courage of high or strong resistance to the state power, and the freedom of expression for the press to exercise the social control for the state (Hiarej 1998). It can even be stated that the sovereign society is the society that has the power and ability to exercising the control over the state and preventing it from the authoritarian decisions and practices as well as the state abuses of power (Manan 2005).

In the views of these two Muslim thinkers, the form of the relationship which is relatively parallel between the state and the society above can reduce the emergence of the tendency of domination by the state over the society or the society over the state (Hiarej 1998). The equality of relation position between the state and the society makes it difficult for each party to force the interests and desires of the other party. The equal position of society-state relation signifies the enactment of the democratic principles requiring the effective state and the sovereign society relationship (Budiman 1990). The position of the sovereign society and the effective state above will create the society-state relation that always has the dialectic of control (Manan 2005).

Their views about the position of the sovereign society and the effective state in the reform era in Indonesia suggest that the state structuring system rests on the essence of the ethics of the statehood in Islam, namely the realization of justice and welfare for all societies. By that way, the effective legitimacy of the state is determined morally and religiously by the functions and actions of the state to uphold and defend justice for the society (Al-Ghazali n.d).

Based on the explanation above, it can be stated that the obedience of the society to the state or the government is conditional namely the state is just and fair and can deliver justice or prosperity to the society. This explanation essentially confirms that the society denotes the source of state or governmental power (Khallaf 1977). This description affirms the universal law that justice is the most important characteristic that must always be inherent in every government or state if it wants to maintain the continuity of its power. In other words, it can be explained that a just state will be sustainable and an unjust state will be unsustainable (Zaidan 
1980). Furthermore, it can also be emphasized that what is meant by the effective state is when the state gets the compliance from the society because the state is able to realize the welfares of its citizens whereas the sovereign society means the fulfilment of the demands of the welfares of all citizens by the state.

In relation to the formulation of a new pattern of the relationship that is equally strong between the two entities named the state and the society, the thoughts of Cak Nur and Gus Dur in addition to considering the existing factors that can strengthen the pattern of the society-state relation also consider the new factors influencing the change in the pattern of the society-state relation in Indonesia connected their Islamic thoughts for the Indonesians. The new factors are categorized into the three factors, namely the cultural factors (Subiyono \& Muttaqin n.d) the rational-instrumental-structural factors, and the factors contributing to the world globalization, especially the strength of the market economy. Both Muslim thinkers consider the three levels of the problems that affect the relationship of the society and the state in the current era in Indonesia in their responses to the changes in the relations and positions of the society in Indonesia in the reform era. The three levels of the problems are namely the local level such as the local culture, the national level such as the constitution of Indonesia, the nation state and democratization, and the global level, such as the universal human rights of the United Nations, the interfaith rights, the minority rights, and the documents of UNESCO related to the educational and vocational rights of children and women.

The description of the responses of Islamic thought as articulated by both Cak Nur and Gus Dur to the changes in society-state relation in Indonesia shows the responsive thinking because there were the similarities and the meeting points, namely the aspects of strengthening the ethical roles and responsibilities of the state towards the lives of Indonesian citizens with their goal is their prosperity and the prosperity of the society. In addition, this thinking is also quite critical of the negative impacts on the society and the state if the Indonesian state implements the capitalist economic system depending solely on the demands and supplies of the market oriented economy.

\section{The Strategy of Islamic Thought Transformation}

The transformation and articulation of Islamic thoughts by both Cak Nur and Gus Dur are related to the rearrangement of society-state relation in Indonesia in the reform era by offering the pattern of relationship between the sovereign society and the effective state. They advance this pattern of relationship for the society and state to secure and maintain the welfare, prosperity and justice existing in the present state system. The choice of the ways or strategies of thinking made by both Cak Nur and Gus Dur can be understood that their vision of Islamic thoughts is to directly change the pattern of the society- state relation in Indonesia in the reform era through the analysis of the Prophetic Social Sciences, namely the social transformation (Kuntowijoyo 2005). The formulation of the concept of social transformation in Prophetic Social Sciences can be explained in the following four steps:

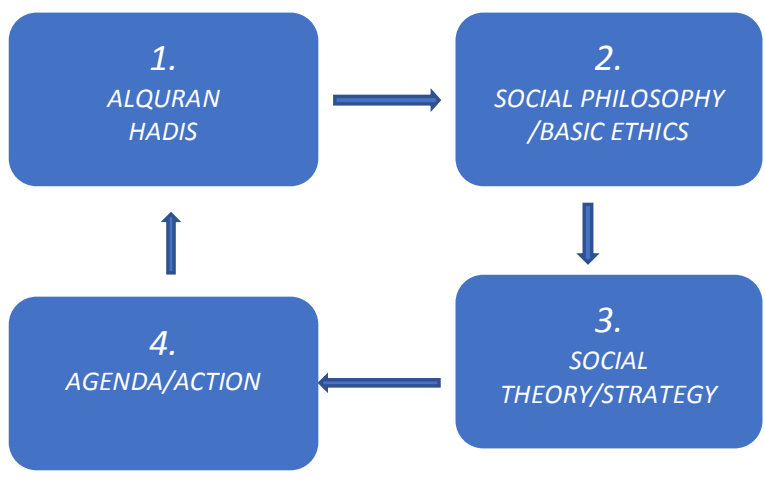


With this line of thinking, it can be understood that Islamic thinking on the society-state relation articulated and advocated by both Cak Nur and Gus Dur presumes that it is impossible to think from the basis of norms of Islam to instantly bring about some changes in the pattern of the society-state relation. In the view of both Cak Nur and Gus Dur, the expected changes are attainable and implementable after the careful and critical study of the macro and philosophical sides of the social reality related to the complexity of the problems of society-state relation in Indonesia in the reform era in various social, economic, cultural, and political fields. In other words, it is necessary to consider the macro and micro sides for social, economic. cultural and political realities and concerns.

Both Muslim Indonesian thinkers show their Islamic thoughts are not limited to explaining the reality and the dynamics of changes in the society-state relation with all the complexity of the problems associated with it, but also devote their dedication to directing and patterning the relation of the two entities. The character of transformative Islamic thought like this is not determined by the technical skills, but by its commitment to realizing the new reality of the life of the state and nation. This new reality is an expression and embodiment of the ethical commitment of the prophetic social sciences. In this connection, the prophetic social sciences demand the hard work of social scientists at the two extreme points. On the one point, they are required to strengthen their understanding of the scientific philosophical rules, precisely strengthening epistemologically based on the ontological appreciation for certain axiological reasons. On the other point, they are required to take part in realizing concretely this philosophical appreciation into everyday scientific practices in the process of creating new social reality (Santoso 2011). Both Cak Nur and Gus Dur probably tend to show to Muslim intellectuals in Indonesia in the reform era by studying the realities before proposing their solutions to the problems as they have initiated through their Islamic thoughts.

Based on this explanation, it can be affirmed that the responses of Islamic thought to the changes in the society-state relation in Indonesia in the reform era as proposed by both Cak Nur and Gus Dur can be read as an intention and awareness to put the basic values for the better and dignified life in the context of the society-state relation. That way, their responses can also be understood as the part of the dynamic movement of the Indonesian Muslim community which is changing when the roots of democracy begin to stick firmly (Hasan 2012).

The explanation above shows that the responses of both Cak Nur and Gus Dur are the Islamic ideas to the changes in the society-state relation originating and deriving from the Islamic teachings as the holistic and comprehensive teaching that has multiple abilities to be continuously reinterpreted in the face of changing times, including the changes in governance and state. Islam has thus been transformed creatively, wisely and contextually by both Cak Nur and Gus Dur in answering political challenges such as the question of nationality and statehood.

The thoughts of these two Muslim Indonesian thinkers can be interpreted as a contribution of Islam which is very meaningful because Islam is an example of most the Indonesian society. This kind of thinking also shows the ability of Muslims to take part in the modern life of the Indonesian state. The Muslims in Indonesia must contribute to their stability and economic prosperity by their more positive and constructive actions which are needed by the Republic of Indonesia. The Islamic thinking of these two Muslim Indonesian thinkers is very contextual, contributively and needed to support and uphold the constitution in the life of the modern nation-state as well as to maintain the continuity of democratic life to realize society's welfare.

In directing some changes in the state-society relation in the Indonesian reform era, both Cak Nur and Gus Dur have succeeded in converging the dimensions of faith and the benefit of nations. Their thoughts show a mature, intelligent, autonomous Islamic thinking. Their Islamic thinking is consisting of interdependent considerations and dialogues as well as bringing together the positive-constructive and proportional approach to the converging point of the faith, the benefit and the common interests to achieve the national unity, peace and society's welfare in the 
format of the nation-state (Adib 2014). In addition, their Islamic thinking is very wise because it takes into consideration the realities of plurality, democracy, inclusiveness in the life of the nation and state as the inseparable parts of the theory of the maslahah as the core of the maqasid alshari'ah. So that the application of this maslahah theory can be applied appropriately in Indonesia in the format of the nation-state based on Pancasila (Abdullah 2014).

Their Islamic thinking in the context of directing changes in the pattern of state-society relation in the Indonesian reform era has presented the religious vision for the good of all parties which can be realized if Islam is understood through the perspectives of the substantive ethical fundamental values, namely the values that can be applied to all components of the citizen (Abdullah 2003). This presupposes that the diversity of cultures, religions, ethnicities, races, genders and social ideologies is not considered an obstacle, but those diversities are managed and considered as the social capital for the realization of democracy and strengthening harmonious and peaceful plural society's public participation. With this concept, society can encourage the state to be fair in providing protection for security and public services to all components of the nation.

This article can be concluded with the two conclusions. The first is the Islamic thought of Nurcholish Madjid and Abdurrahman Wahid in the context of the Indonesian political dynamics in the reform era is an innovative and transformative contribution towards democratization. Their thought encourages the Indonesian nation state to position the sovereign society in full before the state in the sense that it is in accordance with the modern state system so that the state can realize society's welfare.

The second is the Islamic thought as articulated and advocated by both in the context of some changes in the society-state relation stems from the Islamic ethical values which are articulated and transformed creatively into the Indonesian national system. Their thinking presupposes that the reality of the diversity of cultures, religions, ethnicities, races, genders and social ideologies is considered and managed as the social capital for the realization of democracy and strengthening of the public participation of the plural civil society in harmony and peace. On that basis, the Indonesian society can encourage the Indonesian state to be fair in providing protection for security and public services for all Indonesian citizens' society. As such, the political ideas of these two thinkers go beyond procedural democratic thinking.

\section{References}

Abdullah M. Amin. 2014. Islam dan keindonesiaan. In. Komaruddin Hidayat (ed.). Kontroversi Khilafah Islam, Negara dan Pancasila, pp. 195-196. Bandung: Mizan.

Abdullah M. Amin. 2003. Pesan Islam untuk perdamaian dan anti kekerasan. Conference paper. Sidang Tanwir Muhammadiyah, Pesan Perdamaian dan Gerakan Kemandirian Bangsa Menghadapi Krisis Nasional dan Ketidakadilan Global. Universitas Muhammadiyah Makassar Sulawesi Selatan, 26-29 June.

Adib Muhammad. 2014. Tariq Ramadan: Muslim, identitas dan integrasi kewarganegaraan. In. Mirza Tirta Kusuma (ed.). Ketika Makkah Menjadi Seperti Las Vegas, Politik dan Agama. Jakarta: PT. Gramedia Pustaka Utama.

Azhari, Aidul Fitriciada. 2013. Pemikiran Politik Hukum. In. Saldi Isra \& Edy Suandi Hamid (ed.). Sahabat Bicara Mahfud MD. Jakarta: Murai Kencana dan Yayasan Satu Tiga Lima.

Bayyah, Abdullah bin Syaikh Mahfuz bin. 2007. Al-Irhab al-Tasykhis wa al-Hulul. Riyadh: Maktabah al-Ibyikan.

Budiman, Arief. 1990. Introduction: from a conference to a book. In. Arif Budiman (ed.). State and Civil Society in Indonesia. Clayton: Monash University.

Fanani, Muhyar. 2010. Metode Studi Islam Aplikasi Sosiologi Pengetahuan Sebagai Cara Pandang. Yogyakarta: Pustaka Pelajar. 
Al-Ghazali, Abu Hamid Muhammad bin Muhammad al-Thusi. n.d. Al-Tibr al-Masbuk fi Nasihat alMuluk. Beirut: Dar al-Kutub al-Ilmiyah.

Hadiz, Vedi R. 2011. Ketidakadilan Sosial, Akar Radikalisme. Komunitas 3(8): 4-5.

Hadiz, Vedi R. 2016. Islamic Populism in Indonesia and the Middle East. Cambridge: Cambridge University Press.

Haryatmoko. 2003. Etika Politik dan Kekuasaan. Jakarta: Kompas.

Hasan, Noorhaidi. 2012. Jalan Lain Menuju Demokrasi. Foreword. In. Ainur Rofiq al-Amin. Membongkar Proyek Khilafah ala Hizbut Tahrir di Indonesia, pp. xiv-xv. Yogyakarta: LkiS.

Hiariej, Eric. 1998. Hubungan Pembangunan Ekonomi Kapitalis dan Demokrasi: Studi Kasus Korea Selatan. Research Report. Yogyakarta: FISIP-UGM.

Khallaf, Abdul Wahhab. 1977. Al-Siyasah al-Syar'iyah. Cairo: Matba'ah al-Taqaddum.

Kuntowijoyo. 1997. Identitas Politik Umat Islam. Bandung: Mizan.

Kuntowijoyo. 2001. Muslim Tanpa Masjid. Bandung: Mizan.

Kuntowijoyo. 2005. Islam Sebagai Ilmu, Epistemologi, Metodologi, \& Etika. Jakarta: Teraju.

Madjid, Nurcholish. 1995. Islam, Kemodernan, dan Keindonesiaan. Bandung: Mizan.

Madjid, Nurcholish.1998. Dialog Keterbukaan, Artikulasi Nilai Islam dalam Wacana Sosial Politik Kontemporer. Jakarta: Paramadina.

Manan, Munafrizal. 2005. Pentas Politik Indonesia Pasca Orde Baru. Yogyakarta: IRE Press.

al-Mawardi. n.d. Adab al-Dunya wa al-Din. Beirut: Dar al-Fikr.

Mahfud. 2013. Potret Multi Dimensi Gus Dur. In. Foreword, Muhklas Syarkun (ed.). Ensiklopedi Abdurrahman Wahid Riawayat Gus Dur. Jakarta: PPPKI. pp. xi-xii.

Mulkhan, Abdul Munir. 2009. Politik Santri Cara Menang Merebut Hati Rakyat. Yogyakarta: IMPULSE dan Kanisius.

Nafis, Muhammad Wahyuni. 2014. Cak Nur Sang Guru Bangsa Biografi Pemikiran Prof. Dr. Nurcholish Madjid. Jakarta: PT. Kompas Media Nusantara.

Santoso, Purwo. 2011. Ilmu Sosial Transformatif. Pidato Pengukuhan Guru Besar Fakultas Ilmu Sosial dan Ilmu Politik UGM, 19 April.

Santoso, Purwo. 2012. Ilmu sosial transformatif. Millah Jurnal Studi Agama 11(2): 619-620.

Sedarmayanti. 2003. Good Governance (Kepemimpinan yang baik) dalam Rangka Otonomi Daerah. Bandung: Penerbit Mandar Maju.

Subiyono, Aris \& Muttaqin, Tatang. n.d. Studi Pengembangan dan Pemantapan Wujud Ikatan Kebangsaan. (online) http://www.budpar.go.id/filedata/1004_168- Kajian20041.pdf. Retrieved: 24 July 2013.

Toynbee, Arnold Joseph. 1955. A Study of History. New York: Oxford University Press.

Voll, John Obert.1982. Islam: Continuity and Change in the Modern World. Boulder Colorado: Westview Press.

Zaidan, Abdul Karim. 1980. Al-Fard wa al-Dawlah fi al-Shari'ah al-Islamiyyah. Gary Indo: IIFSO. 